\title{
Pillanatképek a jászberényi könyvtárosképzés történetéből
}

\author{
Hábenciusné Balla Andrea
}

\section{Bevezetés}

Ez az írás az Eszterházy Károly Egyetem Jászberényi Campusán és annak jogelődjein folyó informatikuskönyvtáros-képzés történetének több állomását mutatja be. A képzés gazdája ma a Campuson Pedagógiai Kar szervezeti egységeként müködő Tudástechnológiai Intézet, ezen belül pedig az Információs és Kommunikációs Tanszék.

A hazai könyvtárosképzés gondolata elsöként Toldy Ferenc akadémikus fejében született meg, aki 1845 és 1875 között a budapesti Egyetemi Könyvtár igazgatója volt. Ezekben az években a legnagyobb magyar könyvtárakban is kevés könyvtáros dolgozott, leginkább tanárok, köztisztviselök, lelkészek vállalták ezt a feladatot másodállásban. Ebből adódóan a könyvtári munkák legtöbbjét - a könyvek osztályozását, raktározását, kölcsönzési tudnivalókat, illetve a katalogizálást - menet közben sajátították el. A XX. század elején a könyvek számának drasztikus emelkedése eredményeként, valamint az olvasói igények megnövekedésével új könyvtárak jöttek létre, a meglévők pedig gyarapodtak. Kialakultak a szakkönyvtárak, közmüvelődési és államigazgatási könyvtárak, aminek egyik következményeként szükségessé vált a hivatásos könyvtárosok képzése. A tudományos könyvtárakban magasan kvalifikált tudós munkatársak dolgoztak, azonban a gyakorlati tudnivalókat tapasztalatok útján szerezték be, többek között az Országos Széchényi Könyvtárban. Egyik fordulópont volt 1874, amikor az Egyetemi Könyvtár szakvizsga meglétét kérte a kinevezéshez, pár évvel később 1916-ban, Szabó Ervin kezdeményezésére a Fővárosi Könyvtár képzést indított, mely leginkább gyakorlati alapú volt. A könyvtárosi hivatás gyakorlásához szükséges tanfolyamok zajlottak 1928ban az Országos Könyvforgalmi és Bibliográfiai Központ szervezésében, ahol elöadásokon, nagykönyvtári gyakorlatokon tanulhatták a szakmát a résztvevők, azonban állami érvényü bizonyítványt nem kaptak. A magyar könyvtárügy és könyvtártudomány korszakos jelentőségü eseménye volt 1949-ben, hogy a budapesti Pázmány Péter (1950-től Eötvös Loránd) Tudományegyetem Bölcsészettudományi Karán megindult az egyetemi szintü könyvtárosképzés.

Jelentős változást hozott az egyetemi könyvtárosképzésben, amikor Kovács Máté egyetemi tanár, az ELTE tanszékvezetője az addig erőteljesen könyvközpontú és történeti beágyazottságú szemléletet a tágan értelmezett bibliológia 
irányába korrigálta, olyan korszerü tudományokat integrálva a képzésbe, mint a szociológia, az információ- és kommunikációelmélet. Az újabb változások - a könyvtárosképzés megújítása, tudományos presztízsének emelése és a magyar könyvtártudomány nemzetközi kapcsolati rendszerének kiépítése Fülöp Géza egyetemi tanár nevéhez köthetök. A tanszék ekkor már Könyvtár- és Információtudományi Tanszék elnevezéssel, és nevéhez méltón már a korszerü technológiák és az informatika fontosságát állította középpontba.

A jászberényi könyvtárosképzést két nagy részre bonthatjuk. A kezdeti nehézségek, majd a képzés kialakulásának egyik főszereplője dr. Harmat Mária volt, majd a második etap - szintén érdekes fordulatokkal teli - vezetője, dr. Koltay Tibor.

A Jászberényi Tanítóképző Intézet 1917. október 11-én nyitotta meg kapuit. Éveken át a tanítóképzés volt a fő profilja az intézménynek, és csak később alakultak egyéb - a társadalmi igényekhez kapcsolódóan szükségessé vált - szakok. A könyvtárosképzés gondolata és megvalósítása 1975-ben került először terítékre.

A jelenleg éppen kifutó szak indulásáról, nehézségeiröl, változásairól a szakirodalomra, meglévő dokumentumokra, feljegyzésekre, valamint a dr. Harmat Máriával és dr. Koltay Tiborral készített interjúkra hagyatkoztam.

1959-ben volt az első éve a felsőfokú tanítóképzésnek, majd 1975-től tanítóképző főiskolaként folyt tovább az oktatás. A hároméves képzés 1994-ben négy évre nőtt, a tanítóképzés szakpárokkal történő kapcsolódása miatt (tanító-népmüvelő, tanító-könyvtáros), melyekből aztán később új szakok alakultak: andragógia, informatikus könyvtáros, szociálpedagógus és szociális munka. 2000töl a Szent István Egyetem (SZIE) égisze alatt müködött az intézmény önálló főiskolai karként, mely időszakban bővült a képzések profilja. Ekkor a Szent István Egyetem Jászberényi Főiskolai Kar Informatikai és Könyvtártudományi Tanszék neve Szent István Egyetem Alkalmazott Bölcsészeti Kar Informatikai és Könyvtártudományi Tanszékre változott. 2006-tól SZIE Alkalmazott Bölcsészeti Karként szerepelt a föiskola és ekkor egy rövid ideig (2006-2011) a szarvasi Pedagógiai Karral müködött együtt, majd 2016-tól - négy Campus bevonásával megalakult - egri Eszterházy Károly Egyetem Jászberényi Campusaként folytatta munkáját. (Eszterházy Károly Egyetem Jászberényi Campus, 2016) 


\section{A könyvtárosképzés Jászberényben 1975-2004 között}

A jászberényi Tanítóképző Intézet fő profilja mindig a tanítóképzés volt, emellett azonban 1970-töl már könyv- és könyvtárhasználati elméleti alapokat is oktattak a tanítójelölteknek. Kötelező stúdiumként szerepelt a tantervben a Könyvtárhasználati ismeretek tantárgy, mivel minden végzett tanító szakos hallgatónak kötelessége volt a tanulókkal elsajátíttatni az órán hallottakat. Tehát olyan alapismeretre volt szükségük, melynek birtokában később tovább adhatták a gyermekeknek a könyvtárhasználati tudnivalókat. Ez a tantárgy országos szinten került bevezetésre, és később ebből alakult ki a hazai könyvtárosképzés. A Könyvtárhasználati ismeretek tárgyat később megszüntették, pedig manapság is hasznos elméleti és gyakorlati tudnivalókat ismerhetnének meg általa a tanító szakos hallgatók. Jelenleg Információs müveltség néven fut hasonló tantárgy, amelyröl már a képzések kezdetén - a 70-es években - is szó esett. Bár ekkor még korai volt erről beszélni, illetve az oktatás berkeiben nem honosodott meg a fogalom.

A jászberényi könyvtárosképzés tapasztalatairól elsőként dr. Harmat Mária főiskolai docenst kérdeztem, aki szívesen mesélt nekem a 40 éve indult eseményekröl.

Dr. Harmat Mária 1968-ban a debreceni Tanítóképző Főiskola népmüvelőkönyvtáros szakán, majd 1974-ben az ELTE BTK könyvtáros szakán szerzett diplomát és ugyanitt, 1976-ban egyetemi doktori címet szerzett. Harmat tanárnő 1977 óta tanít Jászberényben, és egyik kezdeményezője és vezetője azoknak a képzési formáknak, melyek a szakképzetlen könyvtárosokat alapképzés keretében fontos szakmai ismeretekre tanították, a könyvtár szeretetére, az olvasók megértő tiszteletére nevelték.

A Tanítóképző Főiskolán, a közművelődési tanszéken elsősorban könyvtári tárgyak oktatását végezte. Ekkor a képzés szakkollégiumi rendszerü volt. 1984ben megbízták a közmüvelődési tanszék vezetésével, ezt a vezetői feladatot 1993-ig látta el. 1987-ben föiskolai docenssé nevezték ki. A tanszék vezetőjeként jelentős tartalmi változásokat sikerült elérnie. 1986-ban a könyvtáros szakkollégiumi képzés 10. évfordulójára országos szakmai konferenciát szervezett Jászberényben. 1985-ben ugyancsak Országos Közmüvelődési Konferenciát szervezett a felsőoktatásban dolgozó és kutató kollégák részére. Ennek a színhelye a föiskola volt. 1987-ben a drámajáték tanításának témaköréből ugyancsak országos konferenciát szervezett a jászberényi intézményben. 1988-tól a képzés megújítását célzó kísérlet szakmai vezetője volt. 1993-ban megszünt tanszékvezetői megbízatása, szakfelelösként vezette tovább a könyvtáros szakot 2003-ig, majd az informatikus tanszék megbízott vezetője lett. 1998-ban az 
Országos Széchényi Könyvtárral együtt megszervezte a gyermekkönyvtárosok felsőfokú (posztgraduális) továbbképzését 2 éves kurzus keretében, melynek gyakorlati oktatója Pápainé Kemenczei Judit. Harmat Mária a könyvtárosképzés egész idején mind a nappali, mind a levelező tagozaton szakmai irányító volt. Minden évben indult levelező tagozatos képzés, 4 éven keresztül budapesti konzultációs központtal is, melynek során a gyakorlatot is Budapesten (Statisztikai Könyvtár, Szabó Ervin Könyvtár, Országos Széchényi Könyvtár) végezték a hallgatók (Harmat, 2003).

1975-ben a jászberényi tanítóképzés - az ország többi hasonló intézményével együtt - főiskolai szintre emelkedett. Ugyanebben az évben indult a könyvtári szakkollégiumi képzés a debreceni, győri, kaposvári és jászberényi tanítóképzőkben. A szakkollégiumi képzés egy sajátos jogintézmény volt a magyar nyelvü felsőoktatás rendszerében. Fő célja a szakkollégisták tehetséggondozása, jól informált értelmiségiek képzése és mindemellett megerősítette a tanulók felkészítését egyes készségtárgyak vonatkozásában. Az első időkben két, utána egy szakkollégiumot vehettek fel a hallgatók (ének, rajz, testnevelés, technika, nyelv, könyvtári, népmüvelöi szakkollégium). A legnagyobb előnye ennek a képzési formának, hogy a hallgatók a tanulmányaik befejeztével két szakirányú felsőfokú végzettséggel rendelkeztek. A vélemények eltérőek voltak a szakkollégiumi képzéssel kapcsolatban. A könyvtárvezetök egyöntetüen örömmel fogadták a lépést, a tanítók azonban már nem örültek felhötlenül a szakkollégiumi képzés bevezetésének. Félö volt ugyanis, hogy sok lesz a pályát elhagyó pedagógus.

A könyvtárosképzés ebben az időben már régóta gondokkal küszködött, ugyanis az 1970-es évektől egyre növekvő igény volt a szakképzett könyvtárosokra. Térségünkben az okok között szerepelt a községi könyvtárak felszereltségének és állományának növekedésével arányosan megnövekedett munka mennyisége, illetve a függetlenített munkaidőben dolgozó könyvtárosok munkába állítása. A Jászberényi Tanítóképző Főiskolán a könyvtárosképzés bevezetése óta a helyi Városi Könyvtár adott helyet a könyvtáros szakkollégisták gyakorlati óráinak letöltésére, vezetőjük Horváth Sándorné volt.

A könyvtárosképzés gyakorlata folyamán minden évfolyam más-más területen tevékenykedett, úgymint: feldolgozó munka, olvasószolgálat és gyermekkönyvtár. Általában 10-12 hallgatót fogadtak egyidőben, akik számára a legtöbb munka az olvasószolgálat területén adódott, mivel ott nemcsak a kölcsönzés, hanem sok egyéb momentum is megtanulható, elleshető volt. A tematikát a tanszékvezető készítette el, mely alapján - a Városi Könyvtár általános gyakorlatát is beillesztve a kurzusba - szélesedett a hallgatók látóköre, hiszen alkalmanként a könyvtárosmunkán túl még képzeletbeli író-olvasó találkozót 
is kellett szervezniük. A hat féléves képzés alatt félévenként 20-22 óra állt a diákok rendelkezésére a gyakorlati munka elsajátítására, ami kétheti lebontásban csupán 4 órát jelentett. Ez az idő sokszor kevésnek bizonyult - föként a nagy létszám miatt -, és gondot okozott az is, hogy az előzőleg hallottak és tanultak a következő alkalomra már elfelejtődtek, illetve gyakran nem sikerült befejezni az adott napi munkafolyamatot. Azonban arra ügyeltek a képzés vezetői, hogy az aktuális elméleti ismereteket a gyakorlatot megelőző félévben tanulták a hallgatók, sőt legtöbbször abból az ismeretanyagból le is vizsgáztak (Horváth, 1987).

1985-től a tanítóképzés 4 éves képzési formában ment tovább, ennek következményeként az 1988-as tanévben a Jászberényi és az Esztergomi Tanítóképző Főiskolán kísérleti jelleggel megkezdődött a négyéves, nappali tagozatos tanító-könyvtáros és tanító-népmüvelés szakos képzés. A könyvtári témavezető dr. Harmat Mária tanszékvezető volt. A kutatás célja olyan szakemberek képzése, akik tanítói munkájuk mellett vagy akár önállóan - könyvtárosként is - felvállalják a közösségteremtés szerepét, az iskolán kívüli kulturális nevelés ösztönzését és a könyvtári szolgáltatások ellátását. A tanító szak vezetője és a képzés koordinátora dr. Fábián Zoltán akkori föigazgató volt, aki 1988-ban elkészítette a kísérleti tervtanulmányt és tantervet, valamint óra- és vizsgatervet. Ebben az időszakban az Eötvös Loránd Tudományegyetem oktatói (dr. Fülöp Géza, dr. Szelle Béla) is bekapcsolódtak a képzésbe óraadóként, ezáltal emelkedett a szakmai minőség, hiszen a színvonal megegyezett az ELTE-n folyó oktatással. A képzés az akkori 3 éves időtartamról a szakok integrációjával 4 éves időtartamra emelkedett, amit Jászberényben is örömmel fogadtak, hiszen az addigi 3 éves képzés már kevésnek bizonyult, illetve némi negatív érzéssel töltötte el az intézmény dolgozóit. 1991-ben a záró, értékelő mühelyvita eredményesnek ítélte a kísérletet, és ettől az évtöl már nem kísérleti képzés formájában, hanem elfogadott szakpárként került meghirdetésre a tanító-könyvtáros és a tanító-népmüvelő szakpár 4 éves képzési időkerettel. 1998-ban a MAB (Magyar Felsőoktatási Akkreditációs Bizottság) erős minősítéssel akkreditálta mindkét szakpárt.

A magyar köznevelésben a néptanító modell már 200 éves múltra tekint vissza, amely gyakorlatilag népmüvelő tanítót jelentett. A tanítók egyik célja a gyermekek bevonása a kulturális élet világába, illetve annak tágabb értelemben vett megismertetése és megszerettetése. Innen született meg a gondolat, hogy a tanítóképzésben már oktatott Népmüvelési ismeretek és Könyv- és könyvtárhasználati ismeretek tantárgyakra építve, illetve ezeket tovább gondolva - valamint a szakkollégiumi képzés tapasztalatait felhasználva - elinduljon a 4 éves két szakpáros képzés Jászberényben. 
Az addigi 3 éves tanítóképzés ismeretanyagában sok volt az átfedés, ami okot adott az integrálásra. Fontos szempont volt még a szakpárok elindításánál az a tény, hogy térségünkben (Borsod-Abaúj-Zemplén, Komárom-Esztergom és Jász-Nagykun-Szolnok megyékben) igen magas volt a képesítés nélküli népmüvelök és könyvtárosok száma. A 80-as évek elején könyvtárosképzés csak Nyíregyházán és Szombathelyen volt, ami nem biztosította a megfelelö szakemberlétszámot. Felmerült a posztgraduális képesítés jövőbeni megvalósítása, amihez szintén elengedhetetlenül fontos volt a kapcsolódó szakpárok elindítása. Ennek alapvető feltétele adott volt, mert a tanítóképző iskolák főiskolai rangra emelésével biztosítva lett a képzési idő meghosszabbítása és általa a minőségi munka színvonalának emelése is (Harmat, 1988).

A minisztérium döntése volt, hogy a szakok maradhatnak, de az összekapcsolódást az adott intézmény tanszéke határozta meg. A Jászberényi Tanítóképző Főiskolán szorgalmazták az integrálást, mert úgy ítélték meg, hogy a pályán való elhelyezkedéskor nagyobb esélyt kaptak a hallgatók, ha nemcsak könyvtáros végzettségük volt, hanem két szakpárral rendelkeztek. A föiskola azért is pártolta a többféle képzési formát, mert így nőtt a hallgatói létszám és az intézmény hírneve, ahhoz azonban mereven ragaszkodtak, hogy - a nagy múltú Tanítóképző Intézet nevéhez méltón - a képzés nevében elöl szerepeljen a tanító elnevezés, majd utána a könyvtáros vagy a népmüvelö elnevezés. A már meglévő metodikai képzéseket bevitték a későbbi szakok képzési anyagába, emellett új tantárgyak is bevezetésre kerültek. A szakmai gyakorlat megegyező arányban zajlott mindkét szakpárnál, helyszínei a gyakorló általános iskola és annak könyvtára voltak.

\section{A könyvtárosképzés Jászberényben 2004-2016 között}

1991-1998 között önálló szakként folytatódik a könyvtárosképzés, majd ezt követően könyvtáros-müvelődésszervező szakpárként megy tovább. A szak vonzáskörzete: Jász-Nagykun-Szolnok, Pest, Heves, Nógrád megye és Budapest, de ezeken túl is híre volt a képzésnek, ugyanis az oktatók szívükön viselték a könyvtáros szak múltját és jövőjét. Nagy hangsúlyt fektettek arra, hogy folyamatos fejlödés kövesse az oktatást, és összhang legyen az elméleti és gyakorlati képzés között, illetve a hagyományos és elektronikus könyvtárak közötti összefüggések elemzése sem maradt el. Az egyre fokozódó igények miatt szükséges volt a jövő könyvtárosainak számítógépes és internetes technológiai tudását bővíteni, hiszen nemcsak az olvasói adatbázist kellett karbantartaniuk és használniuk napi szinten, hanem egyéb elektronikus és online forrásokat is 
használnak egy-egy referenszinterjú kapcsán. A szakma által elkészített és országosan elfogadott tantervet igyekeztek megvalósítani Jászberényben is, mivel ez egyenértékü volt a tanárképző tantervével. Ekkor jött az integráció, és a figyelem központjába az informatika került. A tantárgystruktúra kialakítása a könyvtári szakmai bizottság, illetve a tanszék feladata volt, azonban ebben Koltay tanár úr mellett Harmat tanárnő is segédkezett, így ott átláthatóvá vált az informatikai jelleg kialakulása.

1996. október 28-29-én a debreceni Kossuth Lajos Tudományegyetem Komputergrafikai és Könyvtár-informatikai Tanszéke, Kovács Máté Köre, valamint Egyetemi és Nemzeti Könyvtára Kovács Máté művelődéspolitikus, könyvtártudós születésének 90. évfordulója alkalmából emlékülést és könyvtártudományi konferenciát rendezett, melyre meghívták a könyvtárosképző felsőoktatási intézmények - többek között a Jászberényi Tanítóképző Főiskola - oktatóit és hallgatóit. A konferencia döntően az informatika és a könyvtár, könyvtárosképzés kapcsolatáról szólt, hiszen a könyvtártudomány humán tudományból egyre inkább reáltudománnyá vált: több helyen már nem könyvtáros, hanem informatikus könyvtáros szaknak nevezik, s áthelyeződött a természettudományi tanszékekre. A könyvtár és könyvtárosképzés elképzelhetetlen számítógép, informatikai berendezések nélkül, hiszen könnyíti, gyorsítja a keresést, a tájékoztatást. Több, a témában végzett felmérésböl kiderült az is, hogy a gyors, pontos tájékoztatás mellett a könyvtárostól leginkább azt várják el az olvasók, hogy személyes kapcsolatot alakítson ki velük, beszélgetőtársuk legyen. Az emberi szóra és törődésre a 21. század küszöbének technikai felszereltsége mellett is jelentős igény van (Barócsi, 1996).

A magyar könyvtárak és a könyvtárosképző intézmények életében sokáig meghatározó volt a Gombocz-ösztöndíj. Ezt 1974-ben Gombocz István könyvtáros, bibliográfus, jogász emlékére alapították magyar könyvtárosok amerikai tanulmányainak támogatására. Gombocz István 1952-től az Országos Széchényi Könyvtár munkatársa, az IFLA, a Könyvtári Egyesületek és Szervezetek Nemzetközi Szövetsége (International Federation of Library Associations and Institutions) tisztségviselöje volt. Az ösztöndíj nyertesei az Ohio állambeli Kenti Állami Egyetem (Kent State University, KSU) Könyvtártudományi és Informatikai Tanszékének (School of Library and Information Science) programjában vettek részt (Bátonyi és Koltay, 1994). Ez az ösztöndíj a jászberényi könyvtárosképzés ismeretanyagának bővítéséhez is hozzájárult, valamint a tanszék szakmai és pedagógiai programját, hozzáállását is meghatározta az, hogy dr. Koltay Tibor 1991/1992-ben szintén részese volt.

Koltay Tibor 1981-töl több egyetemi és szakkönyvtárban dolgozott. 1993 és 2001 között a Gödöllői Agrártudományi Egyetem (utóbb Szent István Egye- 
tem) könyvtárának igazgatója volt. 1992-től több felsőoktatási intézményben óraadó a könyvtár-informatikai és a szakfordítóképzésben. Kiterjedt nemzetközi kapcsolatrendszerrel rendelkezik, amit az is mutat, hogy öt egyetemen tartott előadásokat ERASMUS-vendégoktatóként. Az a tény, hogy az 1990-es évektől kezdve rendszeresen készít referátumokat, nagyban hozzájárul szakmai horizontjának folyamatos bővítéséhez és naprakészen tartásához.

2004-től a Szent István Egyetem Alkalmazott Bölcsészeti Karon, az időközben önállóvá vált Informatikai és Könyvtártudományi Tanszékének vezetőjeként és az informatikus könyvtáros szak szakfelelősként müködött. Jelenleg ugyanezen intézmény (most már az Eszterházy Károly Egyetem Jászberényi Campusán) folytatja ezt a munkát.

2004-ben alapképzési szak létesítésére irányuló kérelmet 10 könyvtárosképző intézménnyel együtt a Szent István Egyetem is benyújtotta.

Az informatikuskönyvtáros-képzés és elődképzései a Társadalomelméleti, Közmüvelődési és Felnőttképzési Intézet neve alatt zajlottak. 2004-től önálló szervezeti egység, az Informatikai és Könyvtártudományi Tanszék végezte. Az akkori oktatók Báji-Tóth Erika, Jávorszky Ferenc, dr. Koltay Tibor és dr. Prókai Margit dolgoztak fóállásban a tanszéken. Dr. Harmat Mária, aki 1977től 2010-es nyugdíjba vonulásáig a képzés meghatározó szereplője, jelenleg is óraadóként közremüködik az oktatásban. Ezen időszakban az informatikuskönyvtáros-képzés oktatói a Magyar Tudományos Művek Tára (MTMT) tanúsága szerint 13 könyvet, 18 könyvrészletet és 173 folyóiratcikket publikáltak. Ezekre a közleményekre 529 független hivatkozás található az adatbázisban.

A 8 féléves müvelődésszervező-könyvtáros főiskolai diplomát adó képzést előbb az egyszakos, 6 féléves informatikuskönyvtáros-képzés váltotta fel, amelynek folytatása lett a jelenleg még meglevő informatikuskönyvtáros-alapképzés (BA). A korábbi Informatika szakirányú modul ismeretei két specializációba is beépültek. Az Információbróker szakirányú modult felváltó Információmenedzsment az egyike ezeknek, de indult Gyermek- és iskolai könyvtáros specializáció is. 2004-től önálló szervezeti egység, az Informatikai és Könyvtártudományi Tanszék gondozásában, önálló szakfelelőssel, előbb növekvő, majd csökkenő oktatói létszámmal folyt az informatikus könyvtáros hallgatók képzése nappali és levelező tagozaton (Koltay és Tóth, 2005).

2014 óta csak levelező tagozaton folyik az informatikuskönyvtáros-képzés jelenleg kifutó szakként. Az utolsó évfolyam 2016 szeptemberében kezdte meg tanulmányait. A jelentkezési ráta nem csak a jászberényi képzésen mutat csökkenő tendenciát. Az alábbi két táblázatban megfigyelhető a drasztikus változás mind a nappali, mind a levelező tagozatra jelentkezetteknél. 
Pillanatképek a jászberényi könyvtárosképzés történetéböl

\begin{tabular}{|c|c|c|c|c|c|c|c|c|c|}
\hline \multirow{2}{*}{$\begin{array}{l}\text { Felvételi } \\
\text { időszak }\end{array}$} & \multicolumn{4}{|c|}{ Jelentkezók } & \multicolumn{5}{|c|}{ Felvettek } \\
\hline & Összes & $\begin{array}{c}\text { Első } \\
\text { helyes }\end{array}$ & Nappali & Állami & Összes & Nappali & Állami & $\begin{array}{l}\text { Összes - } \\
\text { Nappali }\end{array}$ & $\begin{array}{l}\text { Összes - } \\
\text { Állami }\end{array}$ \\
\hline 2006/Á & 2146 & 953 & 1529 & 1924 & 702 & 362 & 438 & 340 & 264 \\
\hline 2007/Á & 1736 & 588 & 1252 & 1523 & 548 & 328 & 309 & 220 & 239 \\
\hline 2008/Á & 1371 & 435 & 963 & 1208 & 481 & 291 & 329 & 190 & 152 \\
\hline 2009/Á & 1610 & 481 & 1244 & 1492 & 423 & 315 & 307 & 108 & 116 \\
\hline 2010/Á & 1746 & 548 & 1450 & 1603 & 432 & 326 & 290 & 106 & 142 \\
\hline 2011/Á & 1597 & 493 & 1228 & 1436 & 380 & 248 & 241 & 132 & 139 \\
\hline $2012 / \hat{A}$ & 977 & 302 & 774 & 881 & 195 & 147 & 115 & 48 & 80 \\
\hline 2013/Á & 383 & 125 & 276 & 324 & 79 & 54 & 70 & 25 & 9 \\
\hline 2014/Á & 360 & 110 & 275 & 321 & 90 & 63 & 77 & 27 & 13 \\
\hline Összesen & 11926 & 4265 & 8961 & 10712 & 3330 & 2134 & 2176 & 1196 & 1154 \\
\hline
\end{tabular}

1. ábra (Forrás: Könyvtári Figyelö, 2015)

Jelentkezök és felvettek száma az informatikus könyvtáros alapszakra 2006 és 2014 között az általános felvételi idöszakban

\begin{tabular}{|c|c|c|c|c|c|}
\hline \multirow{2}{*}{$\begin{array}{c}\text { Felvételi idő- } \\
\text { szak }\end{array}$} & \multicolumn{2}{|c|}{ ALA } & \multicolumn{2}{|c|}{ "ALK (+2006-2007 között DLK) } & \multirow{2}{*}{$\begin{array}{l}\text { Összes } \\
\text { felvett }\end{array}$} \\
\hline & Első helyes & Felvett & Első helyes & Felvett & \\
\hline 2006/Á & 276 & 123 & 131 & 189 & 312 \\
\hline 2007/Á & 145 & 60 & 90 & 153 & 213 \\
\hline 2008/Á & 116 & 76 & 64 & 103 & 179 \\
\hline 2009/Á & 102 & 20 & 42 & 82 & 102 \\
\hline 2010/Á & 84 & 9 & 43 & 83 & 92 \\
\hline 2011/Á & 100 & 28 & 42 & 90 & 118 \\
\hline $2012 / \mathrm{A}$ & 54 & 5 & 26 & 33 & 38 \\
\hline 2013/Á & 19 & 18 & 11 & 4 & 22 \\
\hline 2014/Á & 24 & 16 & 4 & 0 & 16 \\
\hline Összesen & 920 & 355 & 453 & 737 & 1092 \\
\hline
\end{tabular}

2. ábra (Forrás: Könyvtári Figyelö, 2015)

Az informatikus könyvtáros alapszak levelezö tagozatára 2006 és 2014 között felvettek száma finanszírozási forma szerint bontva

A számok felhívják a figyelmet arra, hogy amennyiben nem történik pozitív változás, úgy hamarosan szakemberhiány léphet fel ezen a területen. Pályakövetési adatok szerint az informatikus könyvtáros végzettségü hallgatók elhelyezkedése nem okoz gondot, föleg azért, mert a könyvtári területen kívül is nagy eséllyel találnak munkát. A Közigazgatási és Igazságügyi Hivatal Közigállás állásportáljának hirdetései is arra utalnak, hogy jelenleg egyre nagyobb az érdeklődés az iskolák részéről a könyvtárostanárok iránt is. Az iskolai könyvtárak ugyanis elsődleges színterei a tanulásnak és a gyermekek könyvtárral való találkozásának.

2013-ban több alapképzés felvételi feltételein szigorítottak, így az informatikuskönyvtáros-képzés felvételi előfeltétele ettől az évtől egy - a szakhoz 
kapcsolódó - eredményes emelt szintủ érettségi megléte (423/2012. (XII.29.) kormányrendelet a felsőoktatási felvételi eljárásról). Az emelt szintủ érettségi előzetes bejelentés nélküli bevezetése meglepte a képzésekre jelentkezőket, így a könyvtárosképzésre jelentkezöket is. Amint az alábbi ábrán is látható - a bevezetés évében, 2013-ban - drasztikus a változás a jelentkezések számában. Azokon a szakokon vezették be a kötelező emelt szintü érettségi meglétét, amelyeken úgy gondolták, hogy csökkenteni kell a hallgatók létszámát. A könyvtáros szaknál már ezt megelözően is volt csökkenés, hiszen nem túl magas ennek a szakmának a presztízse, és a bérek is alulmaradnak más foglalkozásokkal szemben. Nehezíti még a helyzetet, hogy a nagyszámú nyugdíjba vonulás miatt könyvtároshiány lépett fel Magyarországon.

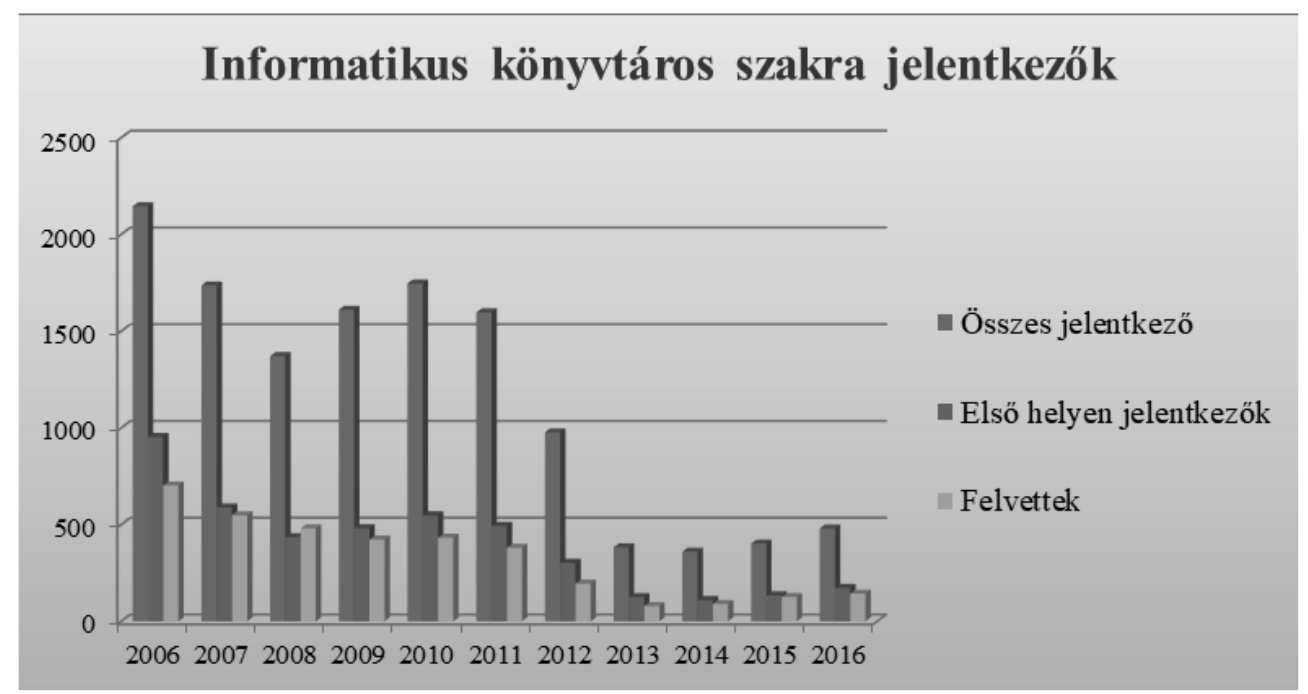

3. ábra (Forrás: Felvi.hu)

Informatikus könyvtáros szakra jelentkezök

\section{Összegzés}

A kutatás során elökerült dokumentumok, illetve beszélgetések arra utalnak, hogy a Jászberényi Tanítóképző Intézet oktatói sok energiát fektettek abba, hogy modern szakokkal töltsék fel a képzést, és a felsőoktatásban lévő többi oktatással egyenrangú legyen. A képzés színvonalát igazolja, hogy többen a diploma megszerzése óta könyvtárosként dolgoznak. A tanító-könyvtáros szak volt a legtermékenyebb, hiszen mindkét végzettséggel elhelyezkedhettek a hallgatók, és ez a párosítás ma is a legkeresettebb az iskolai és a közmüvelödési 
könyvtárakban egyaránt. A nagy múltú Jászberényi Tanítóképző Intézet - jelenleg Eszterházy Károly Egyetem Jászberényi Campusa - könyvtároshallgatói rengeteg tapasztalattal, tudással, kellő szakmai gyakorlattal és szakmai alázattal felvértezve indultak el ezen a pályán, amihez hozzájárultak a képzésben részt vevő oktatók, mentorok, intézményvezetők, tanszékvezetők.

\section{Felhasznált irodalom}

Barócsi Edit Ditta (1996): Könyvtártudományi konferencia. Zsebzsiráf Iskolaújság, 16. 2. sz. 6.

Bátonyi Viola és Koltay Tibor (1994): Mit számít? Gombocz-ösztöndíjasok pályájukról. Könyv, könyvtár, könyvtáros, 3. 9. sz. 51-58.

Eszterházy Károly Egyetem Jászberényi Campus (EKE-JC) (2016): Campus története. https://jaszbereny.uni-eszterhazy.hu/hu/jaszbereny/jaszberenyi-campus/campus-tortenete Letöltve: 2017. június 28.

Harmat Mária (1988): A tanítóképzés és a közmüvelödési szakképzés integrációja. Felnöttoktatási Szemle, 37. 11. sz. 678-680.

Harmat Mária (2003): Önéletrajz. Publikálatlan kézirat.

Harmat Mária (2005): A könyvtár-és információtudományi képzés helyzete és jövője. Országos Pedagógiai Könyvtár és Múzeum, Budapest.

Horváth Sándorné (1987): A könyvtári gyakorlat tapasztalatai egy városi könyvtárban. A Jászberényi Tanítóképző Főiskola, Jászberény.

Koltay Tibor és Tóth Erika (2005): Tradíció, elektronikus könyvtár és informatika a jászberényi könyvtárosképzésben. Jászsági Évkönyv, 2005. 1. sz. $115-124$.

\footnotetext{
Abstract

Snapshots from the history of library science education in Jászberény

The Teacher Traning Institute in Jászberény opened its gates to its students in 1917. Through years the main profile of the institute has been training teachers. Later, adapting to the social trends, other faculties were launched. The idea of training librarians was first introduced in 1975. My publication is about the very beginning of this phasing out course, its difficulties and changes over time, based on documents, notes and interviews with two of its key figures: $\mathrm{Dr}$ Mária Harmat and Dr Tibor Koltay.
} 